\title{
ФЕВРАЛЬСКАЯ БУРЖУАЗНАЯ РЕВОЛЮЦИЯ И ЭКОНОМИЧЕСКАЯ ПОЛИТИКА ВРЕМЕННОГО ПРАВИТЕЛЬСТВА: МАКРОЭКОНОМИЧЕСКИЙ АНАЛИЗ И ИСТОРИЧЕСКИЕ УРОКИ
} Хабаровский государственный университет экономики и права Хабаровск, ул.Тихоокеанская 134, 680049

Kol'tsov V. V. THE FEBRAURY BAURGEOIS REVOLUTION AND ECONOMIC POLICY OF THE PROVISIONAL GOVERNMENT: MACROECONOMIC ANALYSIS AND HISTORICAL LESSONS

\author{
Khabarovsk State University of Economics and Low
}

Khabarovsk, Tikhookeanskaya Street, 134,680049

В данной работе рассматривается возможность использования исторического опьта экономической политики Временного правительства для решения макроэкономических проблем современной России.

Ключевые слова: модель догоняющего развития, макроэкономический анализ, Временное правительство, исторические уроки.

Abstract: This article examines the possibility to use the historical experience in the economic policy of the Provisional government to solve the macroeconomic problems of modern Russia.

Key worlds: catch-up development model, macroeconomic analysis, Provisional government, historical lessons.

Вступление. При разработке стратегии эффективной экономической модернизации современной России необходимо учитывать и использовать исторический опыт социально-экономического поведения государства и правящей элиты не только в периоды благоприятной конъюнктурной ситуации, но и в кризисные периоды экономического развития. Одним из периодов критической зоны развития с серьёзными социально-экономическими аффектами стал кризисный 1917 год. Поэтому актуальной является проблема изучения и анализа макроэкономических причин Февральской революции, особенностей и результатов социально-экономической политики Временного правительства, а также анализ возможности экстраполяции данного исторического опыта в современную реальность России.

История Февральской буржуазной революции получила серьёзное освещение во многих работах по экономической истории страны: например, Белоусов Р. А. Экономическая история России: XX век. Кн.3 / Р. А. Белоусов. М.: АТ, 2003. Однако необходимо дать системный макроэкономический анализ событий и процессов кризисного и «пограничного» для истории экономики страны 1917 года.

Основной текст. Логика экономической истории России всегда формировалась под влиянием модели запаздывающего и догоняющего 
развития, или, по терминологии А. Гершенкрона, модели «догоняющей и отстающей экономической цивилизации». Действие данной модели привело к появлению особого типа капиталистической эволюции России со своеобразной перестановкой фаз и стадий исторического развития: реализация процесса первичной индустриальной модернизации экономики страны при логической незавершённости аграрно-рыночного переворота и низкой эффективности буржуазно-демократического политического переворота.

Интересно отметить тот факт, что в предвоенный период в экономике России наблюдалась ситуация серьёзного по темпам и результатам циклического промышленного подъёма 1909-1913 годов как второго малого цикла интенсивной индустриализации (первый малый цикл индустриализации это циклический промышленный подъём 90-х годов XIX в.).

Стимуляторами предвоенного промышленного подъёма вступили следующие факторы:

1. Появление в отраслевой структуре экономики «новых» отраслей промышленности (электроэнергетика, нефтяной комплекс, сталелитейная, электротехническая и химическая отрасли) под влиянием использования технологий второй мировой технической революции.

2. Позитивный эффект столыпинской аграрной реформы, несмотря на её логическую незавершённость: развитие системы аграрных рынков; спрос на продукцию промышленных отраслей АПК; импорт зарубежных технологий за счёт валютных поступлений от активизации зернового экспорта.

3. Вторая после промышленного подъёма 90-х годов XIX в. своеобразная «волна» новых иностранных инвестиций, особенно в «новые» отрасли промышленности и в банковско-кредитную систему.

4. Реализация в предвоенный период стратегических программ военнопромышленного комплекса и стимулирующее влияние государственных военных заказов.

5. Мультипликативный эффект финансовой политики С. Ю. Витте: золотой стандарт и внешняя конвертация рубля; профицит обыкновенного государственного бюджета; активный торговый и платёжный баланс; система финансовых рынков.

В предвоенный период в российской модели монополистического рынка сложилась весьма парадоксальная ситуация. С одной стороны, относительно высокие темпы промышленного роста за счёт активного использования экстенсивных экономико-географических факторов развития и благодаря притоку в экономику иностранных инвестиций и технологий и появлению железнодорожной логистики с её эффектом мультипликации.

Но, с другой стороны, наблюдалось относительное отставание России от ведущих стран мировой экономики по уровню развития индустриальных технологий, интенсивных факторов модернизации и душевых показателей промышленного роста. Необходимо констатировать логическую незавершённость промышленного переворота с точки зрения процесса первичной машинизации всего экономического комплекса страны. 
По мнению автора данной статьи, в предвоенный период Россия начинает исчерпывать потенциал первичной индустриальной модернизации. Страна должна была по логике искать новые сценарии своей индустриализации, закладывать базу для следующих стадий промышленного роста, но для перехода к индустриальной системе капиталистически-рыночного типа необходимо было логически завершить радикальную аграрно-рыночную и буржуазно-демократическую политическую модернизацию страны. Но логическая нерешённость аграрного вопроса и низкая эффективность буржуазно-демократических политических и государственных институтов страны в предвоенный период явились в дальнейшем серьёзными институциональными причинами Февральской и Октябрьской революций.

Первая мировая война оказала достаточно противоречивое влияние на российскую экономику: с одной стороны, благоприятная конъюнктурная ситуация для ускоренного развития отраслей военно-промышленного комплекса, но, с другой стороны, серьёзные трудности были в отраслях потребительского комплекса, в аграрном секторе экономики и в сфере железнодорожного транспорта. Но наиболее проблемным оказался финансовый сектор экономики: хронический дефицит госбюджета; эмиссия обесцененных бумажных денег и инфляционный мультипликатор; отказ от золотого стандарта рубля; пассивный торговый и платёжный баланс; внутренний и внешний государственные долги.

Но наиболее серьёзный экономический и социально-политический кризис в стране появился в 1917 году. Россия оказалась в критической зоне развития с предельным экономическим и политическим напряжением общества и социальными аффектами. $\mathrm{K}$ сожалению, после Февраля социальноэкономическая политика Временного правительства оказалась малоэффективной вследствие комплекса деструктивных причин:

1. Негативное воздействие военной конъюнктуры на экономическую ситуацию вследствие продолжения участия России в войне.

2. Ситуация политического двоевластия после февраля 1917 года: противостояние Временного правительства и Советов народных депутатов.

3. Отсутствие у Временного правительства эффективной макроэкономической программы действий и ситуационный характер экономической политики.

4. Нестабильность партийной и социальной основы четырёх составов правительства, которая отразилась на колебаниях его экономической политики.

Таким образом, Временное правительство не сумело вывести Россию из ситуации макроэкономического и социального кризиса, что привело к объективности и логичности прихода большевиков к власти в октябре 1917 года.

\section{Заключение и выводы.}

Анализ процессов Февральской революции и экономической политики Временного правительства позволяет напомнить правительству и экономической элите современной России те исторические уроки и аксиомы, о которых неоднократно писал автор данной статьи в своих публикациях: 
1. Необходимость сбалансированности экономической модернизации и адекватной модернизации и реформирования политических и государственных институтов.

2. Повышение эффективности системы государственного экономического маркетинга: на основе макроэкономического анализа своевременно использовать методы индикативной профилактики и управления, не запаздывать с проведением реформ и не доводить экономическую ситуацию до кризиса или критического предела.

3. Создавать эффективную систему государственного экономического менеджмента, чтобы реформы были качественными и логически завершёнными и проводились в интересах нации, но не в интересах олигархического капитала и правящей элиты.

4. Правительство должно иметь макроэкономическую стратегию инновационной модернизации, не ограничиваясь использованием «пожарных» методов ситуационной политики (как Временное правительство).

5. Усилить внимание к эффективному развитию социальной сферы экономики, чтобы не допускать социального напряжения в обществе и социальных аффектов, тем более, что социальная ситуация в стране серьёзно ухудшается.

Литература:

1. Белоусов Р. А. Экономическая история России: XX век. Кн.3 / Р. А. Белоусов. - М. : АТ, 2003.

Статья отправлена: 23.03.2017

(C) Кольцов В. В.

ЦИТ: иа117-042

DOI: 10.21893/2415-7538.2016-05-1-042

УДК 338

Сазонова Е.О., Солдатова Л.А.

ВЛИЯНИЕ ФИНАНСОВЫХ ИНСТИТУТОВ НА ДИНАМИКУ И

СТРУКТУРУ ПОТРЕБЛЕНИЯ

Оренбургский государственный университет,

Оренбург, пр. Победы 13, 460018

Sazonova, O. E., Soldatova L. A.

THE IMPACT OF FINANCIAL INSTITUTIONS ON THE DYNAMICS AND STRUCTURE OF CONSUMPTION

Orenburg state University,

Orenburg, Pobedy 13, 460018

Аннотация. В работе рассматривается характер прямого и косвенного влияния финансовых институтов на сферу потребления в российской экономике. В частности, - наиболее актуальная на сегодняшний момент проблема - дестабилизации потребления со стороны финансовых институтов. Показана противоречивость интересов финансового института 